\title{
THE EXPERIENCE OF A NURSE IN THE RESIDENCY MULTIDISCIPLINARY DEPLOYED IN PALMAS-TO
}

\author{
A EXPERIÊNCIA DE UM ENFERMEIRO NA RESIDENNCIA MULTIPROFISSIONAL \\ IMPLANTADA EM PALMAS-TO
}

\author{
Lorraine Dias BRANDÃO ${ }^{1,2 *}$; Tales Alexandre AVERSI-FERREIRA ${ }^{2}$ \\ 1. Graduation in Health Science, Federal Universtiy of Tocantins, Palmas, TO, Brazil; 2. Laboratory of Biomathematics, Institute of \\ Biomedical Sciences, Federal University of Alfenas, Alfenas, MG, Brazil. lorraine.brandao@ hotmail.com
}

\begin{abstract}
The experiences of the participants of residency programs should be used to increase the data on the progress and quality of these continuing education activities. The aim of this study was to show the perspective of one of these professionals of challenges and insertion as member of the Family Health Strategy team and students of a multiprofessional residency program in Northern Brazil. To support this report, a literature search was conducted used indexes Pub med, Open access, Lilacs, Google Scholar and Virtual Health Library, giving priority to the most recent articles. The role of residents in Basic Health Units allowed higher number of receptions, residential visits, formation of health groups and incentives to health promotion practices. Residents were positively stimulated to meet the goals taught in classes and maintained a commitment to the legal proposals for the implementation of health quality. The implementation of the Multidisciplinary Residency Program in Family and Community Health in Palmas - TO faced some difficulties, however it allowed residents to reflect on their practices and the multidisciplinary integration in the production of actions and improve the quality of care, contributing to broadening the perspective on the health / disease process based on a realistic health situation in the country.
\end{abstract}

KEYWORDS: Specialization. Family Health Strategy. Education Continuing.

\section{INTRODUCTION}

Primary Health Care (PHC) in Brazilian cities via Basic Health Units (BHU) and Family Health Strategy teams (FHS) have not provided, at least so far, adequate care to the general population, according to the final report of the XIV National Health Conference (BRASIL, 2011) and corroborated by other authors (PUCCINI; CORNETTA, 2008; BREHMER; VERDI, 2010; MACHADO et al., 2011; RABETTI; FREITAS, 2011; JUNQUEIRA; DUARTE, 2012)

In fact, most patients who are received in BHU seek care in the Emergency Medical Unit (EMU) (MARQUES; LIMA, 2017; OLIVEIRA et al., 2013; LUDWIG; BONILHA, 2003), which are not the priority door of access to the Unified Health System (UHS), overloading these units and compromising the quality of care to the population (RANDOW et al., 2011; OLIVEIRA et al., 2015). Indeed, it appears to be normal for Brazilian population the use of the EMU for cases where the medical appointment takes a long time (MARQUES; LIMA, 2017) or for acute, emergencial or intercurrent cases from specialized units (LUDWIG; BONILHA, 2003).

One must keep in mind that the Family Health Strategy (FHS) should at least facilitate access to health care and contribute to improving the quality of public services (TAKEMOTO; SILVA, 2007; TADDEO et al., 2012), mainly if the directions to follow the Ambulatory Care-Sensitive Conditions (ACSC) that preconize a conjunct of solutions to diminish the number of hospitalizations whether the Primary Health Care was adequately used by the system, in fact because the activities as disease preventions, chronic or acute and early diagnosis, it generates a logical consequence of the diminution of the hospitalizations (AFRADIQUE et al., 2009).

The associated information to ASCS was published in Brazil in 2008 (BRASIL, 2008), indicating groups of hospitalization for caresensitive conditions to Primary Health Care, as well, preventive disease by immunization, gastroenteritis infectious, anemia, nutritional deficiency, ear, nose and throat infections, bacteria's pneumonia, asthma, lung diseases, hypertension, angina, diabetes mellitus, kidney and urinary tract infection (FERREIRA et al., 2014).

To make effective the healthy strategies it is necessary to implement the norms of the Federal resolutions. Indeed, the non-implementation of projects linked to the organization of health services proposed by the Ministry of Health could have many causes, inter alia, for reasons such as the small amount of health centers (PEDROSA et al., 2011; VITORIA et al., 2013; CASANOVA; REGO, 
The experience of...

2014) due to bureaucratic problems caused by the inadequacy of public administration to prioritize the basic needs of the population (MEDEIROS et al., 2010; SCHWARTZ, et al., 2010), and, among other factors, to the lack of health professionals with little or no adequate profile to implement care activities at Basic Health Units (MORETTI-PIRES; BUENO, 2009; BATISTA; GONÇALVES, 2011; GONZE; SILVA, 2011; SILVA et al., 2011; VALERETTO et al, 2011; MARQUES et al., 2014).

According Paim and colleagues (2011) the Unified Healthy System (UHS) in Brazil increased the access of the population to the health care with an evolution in the last 20 years with the System Unique of the Health (SUS) implementation, promoting the national access for vaccination and prenatal assistance; however, this system must be more development and depends of politics effort for to continue and become better for guarantee the equality and universal health assistance.

In considering the health professional formation as part of the health program, one of the several options to improve the profile of these is the implementation of training centers to generate strategies to maintain health professional in the inland of the country (RAMALHO; MADEIRA, 2005; CAVALHEIRO; GUIMARÃES, 2011; BRASIL, 2012) and in areas of difficult access and provision such as the Northern and Northeastern regions of Brazil (CAMPOS et al., 2009; OLIVEIRA et al., 2013; PINHEIRO; SILVEIRA, 2014), thus expanding health residency spaces (medical and multidisciplinary), with priority on family health and other areas where there is lack of UHS professionals linked to health internalization policies such as professional training and salary and career incentives (BRASIL, 2012).

Considering the various strategies to train health professionals, residency encourages them to obtain a critical-reflective look to transform health practices in terms of resolution and implementation of quality of health services, with a humanistic, critical and integrating perception that meets demands via the execution of concrete actions aimed at the health of the population (NASCIMENTO; OLIVEIRA, 2006; FERNANDES; BACKES, 2010; FERREIRA et al., 2010; MAIA et al., 2013).

In addition to factors mentioned above, residency programs guarantee and strengthen the Continuing Health Education (CHE) providing the continuing education proposed by the Law of Guidelines and Bases of National Education (BRASIL, 1996), that states about the primary, secondary and tertiary levels of Health Care, qualify
BRANDÃO, L. D.; AVERSI-FERREIRA, T. A.

health professionals and NHS managers, and promote improvements in the service to users, inter alia, especially if partnerships are established with public education institutions (BRASIL, 2012); however, this has been done from only in a punctual way, fragmented, discontinuous and without the importance of comprehensive care (BARSAGLINI et al., 2015; IBIAPINA et al., 2015).

The experiences of health professionals who participate and are part of continuing education activities in residency programs must be used to increase data on the progress and quality of these continuing education activities, enabling these professionals to observe whether or not they are being only receptacles or accumulators of knowledge, which, according to Paulo Freire (1970), reduces the critical view of these subjects. In fact, the implementation of multidisciplinary residency programs should also encourage research on priority issues for the health of the population that if performed in a timely manner, will contribute to the improvement of UHS (CELINO; COSTA, 2013).

However, it is important to hypothetically verify if residency programs meet the commitment of preparing health professionals for care directed at patients and provides an option for continuing education.

Considering some functions of the nurse, they are important members within the multidisciplinary team that composes the FHS (ALVIM; FERREIRA, 2007; MATUMOTO et al., 2011) and, also, is an active component in the process of consolidation of this strategy, enabling an integrative and humanized health policy that, among other advantages, has represented to this professional, a field of growth and social recognition (AMORIM; ANDRADE, 2009; ARRUDA et al., 2014; FREITAS; SANTOS, 2014; MAZZUCHELLO et al., 2014; MOURA et al., 2015), allowing the fulfillment of this professional according to the National Primary Care Policy (BRASIL, 2011).

Based on above citations, to show how the nurse suits within multi- professional residency programs, this descriptive-qualitative report aims put in evidence the perspective of one of these professionals, your challenges and insertion as member of the Family Health Strategy team as a student of a multi-professional residency program in Northern Brazil.

Factors like humanization, completeness and appropriateness to the purpose for which multiprofessional residency programs are proposed will be critically examined, with emphasis on advantages 
The experience of...

and disadvantages, even though subject to the inherent subjectivity as a component of this system in order to strengthen the foundations to support a better implementation of public health policies, and the nurse is one of the health care professionals included in these programs.

\section{CONTENT}

The City of Palms has 36 BHU, 2 EMU and 3 public hospitals for free treatment of the population, and is in quantitative terms, one of the largest Brazilian capitals in number of public health care centers of northern Brazil.

In order to promote the inclusion of qualified health professionals into the labor market and especially in the priority areas of UHS, as recommended by Ordinance No. 11.129 (2005), the Multidisciplinary Residency in Family and Community Health was implemented by the city of Palmas. The support from the Ministry of Health and Municipal Health Fund has provided Research scholarships for Education through Work-PET / Palmas with objectives, among others, to encourage further research applied to UHS (PALMAS, 2014).

For the implementation of the Multidisciplinary Residency Program in Family and Community Health, lectures, tutorials, preceptors and practical work at the BHU, EMU were offered in specialized centers and management. This type of education characterized by in-service training has been widely used in order to train skilled professionals to work in this new care model, and the reports already available proved that the proposal is successful (GUILHERME et al., 2012; MELO et al., 2014; SILVA et al., 2015), a result that demonstrates the importance of the association between theory and practice in professional instrumentation to properly develop actions in the community (FERREIRA et al., 2010; SILVA et al., 2015).

Specifically, for works in BHU, teams were formed according to classification in the selection process to join the residency program and positions were offered by the board of primary health care units. Teams were composed of resident physicians and nurses or mixing a category of residents with others from the municipal health department already working at BHU. Residents then fill the spaces of work teams at BHU. There were at least two cases where multidisciplinary teams were composed only of residents. The approach of residents with Primary Care servers favors professional practice and work organization changes, enabling improved quality of
BRANDÃO, L. D.; AVERSI-FERREIRA, T. A.

care (GONZÁLEZ; ALMEIDA, 2010; MARIN et al., 2014).

According to Ordinance 2448/2011, the multidisciplinary team of the family health strategy must be composed at least of "generalist physician or specialist in family health or family and community doctor, generalist nurse or specialist in family health, auxiliary or technician and Community Health Agents (CHA), which may also include oral health professional as part of the multidisciplinary team: generalist dentist or specialist in family health, assistant and / or technician in Oral Health" and "the number of CHA should be sufficient to cover $100 \%$ of the registered population, with up to 750 people per CHA and 12 CHA per Family Health team, not exceeding the maximum recommended of people per team".

The teams composed of residents contained the minimum number of professionals recommended by Ordinance 2448/2011; however, additional professionals who joined the residency program, psychologists, nutritionists, physiotherapists and social workers, and those that formed the Center for Family Health Support (CFHS) were not sufficient to provide support for all BHU, thus, interdisciplinary training proposed by the Multidisciplinary Residency was not completely satisfied, thus reducing the comprehensiveness of the health care service. In fact, the multidisciplinary work in Primary Care is of paramount importance as it provides knowledge exchange and interdisciplinary care, contributing to humanization and comprehensive care, actions consistent with the principles of UHS (CASATE; CORRÊA, 2012; GUILHERME et al., 2012; MAIA et al., 2013; JUNIOR et al., 2015).

In general, the actions of residents in BHU groups allowed higher number of receptions, residential visits and community served, formation of health groups and incentives to health promotion practices and disease prevention, as they increase the components of existing groups and at least two other health groups have been created. These actions collaborate in preventing hospitalizations, injuries and early deaths, improving health indicators and reducing costs (JUNQUEIRA; DUARTE, 2012; RAMOS et al., 2013).

One fact to consider is the relationship between quantity and quality in the health care provided to the population. The aforementioned quantitative data were recorded at the end of the day when the number of attendances was cited by receptionists, not always on a daily basis. In cases where the multidisciplinary team was composed only of residents, these were composed of two 
doctors, two nurses, one nursing technician and health workers, which means twice as many nurses and doctors as in the other groups.

However, even with twice as the number of health professionals in teams of residents, the number of receptions did not double compared to the other groups, because priority was given to quality of care along with health promotion and disease prevention. This probably occurred due to the theoretical focus given to residents in classes held on Saturdays, Fridays afternoon and Thursdays with night teachers. In these classes, teachers always focused on quality of care, disease prevention and reception optimization, according to recommendations of the Ministry of Health (BRASIL, 2012).

Thus, the residency program fulfilled the expectations of the federal government to prioritize quality of health promotion and disease prevention (BRASIL, 2012) with increased number of home visits and creation of support groups of health promotion and disease prevention carried out by the group of residents. It also allowed, with the increased number of receptions at BHU, reducing overload at EMUs, and providing a comprehensive and humane care (NOBREGA; ARRUDA, 2012; JUNIOR et al., 2015).

It was observed that residents were positively stimulated to meet the goals taught in classes and maintained themselves committed to the legal propositions for quality implementation in health care. A plausible explanation of these positive stimuli may be associated with the age of residents, mostly young people freshly out of university, full of ideals still not mutilated by social difficulties found in the profession (COLENCI; BERTI, 2012), who joined a Multidisciplinary Residency program focused on family and community health. It could be inferred that this choice is accompanied by a great humanitarian ideal, an inner motivation that enabled greater workforce.

Residents have not yet experienced the stress of daily work in health units caused by various factors such as low wages (JUNIOR et al., 2015), stress due to lack of materials (PEDROSA et
BRANDÃO, L. D.; AVERSI-FERREIRA, T. A.

al., 2011), continuous care to the population (SÁ et al., 2014), among other of personal aspects.

However, it was found that the participation of residents in new or operating groups generated an increase in production in terms of receptions and motivation in groups without residents that were already in operation. It could be inferred that, somehow, members of the health promotion teams, being or not part of the residency program, were encouraged to improve their actions. The causes can be various, from the building of a new environment with the coming of residents up to motivational of social factors and those of personal origin. Since it is a complex foundation behavior, studies aimed at changing the behavior of health professionals in relation to new members and environmental changes should be considered, as stimulating factors should be developed by health managers to improve the actions of these professionals within a humanitarian context and minimizing the constant stress observed in these professionals (PEDROSA et al., 2011; SÁ et al., 2014; JUNIOR et al., 2015).

Another aspect is that most experienced professionals shared their knowledge and experiences with residents (MELO et al., 2014) and this knowledge exchange can be an indicator of improved self-esteem through the act of teaching.

It could be concluded that the implementation of the Multidisciplinary Residency Program in Family and Community Health in Palmas - TO faced some difficulties such as insufficient number of professionals at CFHS to support all BHUs; however it allowed residents to reflect on their practices and the multidisciplinary integration in the production of actions and improve the quality of care, contributing to broadening the perspective on the health / disease process based on a realistic health situation in the country and on the wisdom of more experienced professionals and skilled teachers.

\section{ACKNOWLEDGEMENTS}

The first author thanks PET-Palmas by scholarship and the last author thanks $\mathrm{CNPq}$ for Productivity Scholarship in Research.

\footnotetext{
RESUMO: As experiências vividas pelos profissionais de saúde participantes de residências devem ser usadas para aumentar os dados sobre o andamento e qualidade dessas atividades de educação continuada. O objetivo deste trabalho é mostrar a visão de um desses profissionais frente aos desafios e sua inserção como membro da equipe de Estratégia de Saúde da Família e discente de uma residência multiprofissional na região Norte. Para apoiar este relato foi realizada uma pesquisa bibliográfica nas bases de dados PubMed, Lilacs, Google Acadêmico e Biblioteca Virtual em Saúde, com prioridade para artigos mais recentes. A atuação dos residentes nos grupos das Unidades Básicas de Saúde permitiu maior número de acolhimentos, visitas residenciais, formação de grupos em saúde e estímulos às práticas de
} 
promoção à saúde. Os residentes se apresentavam estimulados positivamente a cumprir as metas ensinadas nas aulas e mantiveram um comprometimento com as proposições legais para a implantação da qualidade em saúde. A implementação do Programa de Residência Multiprofissional em Saúde da Família e Comunidade em Palmas - TO enfrentou algumas dificuldades, entretanto permitiu aos residentes refletir sobre suas práticas e a integração multidisciplinar na produção de ações e melhoraria da qualidade do atendimento, contribuindo para ampliar a perspectiva sobre o processo saúde / doença com base na situação de saúde real do país.

PALAVRAS-CHAVE: Especialização. Estratégia Saúde da Família. Educação continuada.

\section{REFERENCES}

AFRADIQUE, M. E.; BONOLO, P. F.; DOURADO, I.; LIMA-COSTA, M. F.; MACINKO, J.; MENDONÇA, C. S.; OLIVEIRA, V. B.; SAMPAIO, L. F. R.; DE SIMONI, D.; TURCI, M. A. Internações por condições sensíveis à atenção primária: a construção da lista brasileira como ferramenta para medir o desempenho do sistema de saúde (Projeto ICSAP-Brasil). Cadernos de Saude Publica, Rio de Janeiro, v. 25, n. 6, p. 13371349 , jun 2009.

ALVIM, N. A. T.; FERREIRA, M. A. Perspectiva problematizadora da educação popular em saúde e a enfermagem. Texto e Contexto Enfermagem, Florianópolis, v. 16, n. 2, p. 315-319, jun. 2007.

AMORIM, M. M.; ANDRADE, E. R. Atuação do enfermeiro no PSF sobre aleitamento materno. Perspectivas online, Campos dos Goytacazes, v. 3, n. 9, p. 93-110, dez. 2009. https://doi.org/10.1590/S010407072007000200015

ARRUDA, L. P.; MOREIRA, A. C. A.; ARAGÃO, A. E. A. Promoção da saúde: atribuições do enfermeiro como educador na estratégia saúde da família. Essentia, Sobral, v. 16, n. 1, p. 183-203, nov. 2014.

BARSAGLINI, R. A.; PAZ, K. M.; LEMOS, P. L. Qualidade de vida e cuidado á pessoas com doença falciforme. Interface, Botucatu, v. 19, n. 52, p. 195-199, mar. 2015.

BATISTA, K. B. C.; GONÇALVES, O. S. J. Formação dos Profissionais de Saúde para o SUS: significado e cuidado. Revista Saúde e Sociedade, São Paulo, v. 20, n. 4, p. 884-899, dez. 2011.

https://doi.org/10.1590/S0104-12902011000400007

BRASIL. Casa Civil. Lei n. 9.394, de 20 de dezembro de 1996. Estabelece as Diretrizes e Bases da Educação Nacional. Diário Oficial [da] República Federativa do Brasil. Brasília, DF, 23 dez.1996. Disponível em: $<$ <ttp://www.planalto.gov.br/ccivil_03/LEIS/L9394.htm>. Acesso em: 01 jun. 2015.

BRASIL. Casa Civil. Lei n. ${ }^{\circ} 11.129$, de 30 de junho de 2005. Institui o Programa Nacional de Inclusão de Jovens - ProJovem; cria o Conselho Nacional da Juventude - CNJ e a Secretaria Nacional de Juventude; altera as Leis $\mathrm{n}^{\mathrm{o}} \mathrm{s} 10.683$, de 28 de maio de 2003, e 10.429, de 24 de abril de 2002; e dá outras providências. Diário Oficial [da] República Federativa do Brasil, Brasília, DF, 01 jul. 2005. Disponível em:

<http://www.planalto.gov.br/ccivil_03/_Ato2004-2006/2005/Lei/L11129.htm>. Acesso em: 01 jun. 2015.

BRASIL. Ministério da Saúde. Portaria n ${ }^{\circ} 221$, de 17 de abril de 2008. Publica a lista brasileira de internações por condições sensíveis à atenção primária. Diário Oficial [da] República Federativa do Brasil, Brasília, p. 70, 18 abr. 2008. Seção 1.

BRASIL. Ministério da Saúde. Portaria n. 2448 , de 21 de outubro de 2011. Aprova a Política Nacional de Atenção Básica, estabelecendo a revisão de diretrizes e normas para a organização da Atenção Básica, para a Estratégia Saúde da Família (ESF) e o Programa de Agentes Comunitários de Saúde (PACS). Diário Oficial [da] República Federativa do Brasil, Brasília, DF, 24 out. 2011. Disponível em:<http://bvsms.saude.gov.br/bvs/saudelegis/gm/2011/prt2488_21_10_2011.html>. Acesso em: 01 jun. 2015. 
BRASIL. Ministério da Saúde. Política Nacional de Atenção Básica. Brasília, DF, 2011. 37 p.

BRASIL. Ministério da Saúde. Relatório final da 14ª Conferência Nacional de Saúde. Brasília, DF, 2012. 232p.

BREHMER, L. C. F.; VERDI, M. Acolhimento na Atenção Básica: reflexões éticas sobre a Atenção à Saúde dos usuários. Ciência \& Saúde Coletiva, Rio de Janeiro, v. 15, n. 3, p. 3569-3578, nov. 2010.

CALDERERO, A. R. L.; MIASSO, A. I.; CORRADI-WEBSTER, C. M. Estresse e estratégias de enfrentamento em uma equipe de enfermagem de Pronto Atendimento. Revista Eletrônica de Enfermagem, Goiânia, v. 10, n. 1, p. 51-62, mar. 2008. Disponível em:

<https://www.fen.ufg.br/fen_revista/v10/n1/v10n1a05.htm >. Acesso em: 29 jul. 2015.

CAMPOS, F. E.; MACHADO, M. H.; GIRARDI, S. N. A fixação de profissionais de saúde em regiões de necessidades. Divulgação em Saúde para Debate, Rio de Janeiro, v. 1, n. 44, p. 13-24, maio. 2009.

CASANOVA, M. R. R. Qualidade no atendimento no Pronto Socorro municipal de Pelota/RS. Revista Eletrônica Acadêmicus, Pelotas, v. 2, n. 2, p. 49-63, jan. 2014. Disponível em:

$<$ https://periodicos.ufpel.edu.br/ojs2/index.php/Academicus/article/view/3849/3626 >. Acesso em: 29 jul. 2015.

CASATE, J. C.; CORRÊA, A. K. The humanization of care in the education of health professionals in undergraduate courses. Revista da Escola de Enfermagem da Universidade de São Paulo, São Paulo, v. 46, n. 1, p. 212-218, fev. 2012.

CAVALHEIRO, M. T. P.; GUIMARÃES, A. L. Formação para o SUS e os desafios da Integração Ensino e Serviço. Caderno do Fórum Nacional de Educação das Profissões na Área da Saúde, São Paulo, v. 1, p. 19-27, dez. 2011.

CELINO, S. D. M.; COSTA, G. M. C. Pesquisa para o sistema único de saúde na Paraíba: operacionalização e gestão de recursos financeiros. Revista Baiana de Saúde Pública, Bahia, v. 37, n. 3, p. 757-774, set. 2013.

COLENCI, R.; BERTI, H. W. Formação profissional e inserção no mercado de trabalho: percepções de egressos de graduação em enfermagem. Revista Escola Enfermagem Universidade São Paulo, São Paulo, v. 46, n. 1, p. 158-166, fev. 2012. https://doi.org/10.1590/S0080-62342012000100022

FERNANDES, M. C. P.; BACKES, V. M. S. Educação em saúde: perspectivas de uma equipe da Estratégia Saúde da Família sob a óptica de Paulo Freire. Revista Brasileira de Enfermagem, Brasília, v. 63, n. 4, p. 567-573, ago. 2010.

FERREIRA, M. L. S. M.; COTTA, R. M. M.; LUGARINHO, R.; OLIVEIRA, M. S. Construção de Espaço Social Unificado para Formação de Profissionais da Saúde no Contexto do Sistema Único de Saúde. Revista Brasileira de Educação Médica, Manguinhos, v. 34, n. 2, p. 304-309, out. 2010.

FERREIRA, R. C.; FIORINI, V. M. L.; CRIVELARO, E. Formação Profissional no SUS: o Papel da Atenção Básica em Saúde na Perspectiva Docente. Revista Brasileira de Educação Médica, Manguinhos, v. 34, n. 2, p. 207-215, out. 2010.

FREIRE, P. Pedagogia do Oprimido. Rio de Janeiro: Paz e Terra, 1970.

FREITAS, G. M.; SANTOS, N. S. S. Atuação do enfermeiro na Atenção Básica de Saúde: Revisão integrativa de Literatura. Revista de Enfermagem do Centro Oeste Mineiro, Divinópolis, v. 4, n. 2, p. 1194-1203, ago. 2014.

GONZÁLEZ, A. D.; ALMEIDA, M. J. Integralidade da saúde - norteando mudanças na graduação dos novos profissionais. Ciência \& Saúde Coletiva, Rio de Janeiro, v. 15, n. 3, p. 757-762, maio. 2010. 
GONZE, G. G.; SILVA, G. A. A integralidade na formação dos profissionais de saúde: tecendo valores. Physis Revista de Saúde Coletiva, Rio de Janeiro, v. 21, n. 1, p. 129-146, maio. 2011.

GUILHERME, F.; CALLEGARI, D.; CARVALHO, B. G.; IGLECIAS, V. A.; SANTOS, E. R.; CAMPRENGUER, E. S. Reflexões de uma equipe de residentes multiprofissionais em saúde da família sobre o processo de reativação de um Conselho Local de Saúde. Revista brasileira medicina da família e comunidade, Florianópolis, v. 7, n. 25, p. 265-271, dez. 2012.

IBIAPINA, A. R. L.; FREIRE, A. L. L.; MATOS, C. V.; VIEIRA, N. H.; CARVALHO, P. I. N.; MOURA, T. N. Educação popular na Atenção Básica: um enfoque na integralidade. Revista Eletrônica Gestão \& Saúde, Curitiba, v. 6, n. 1, p. 785-792, mar. 2015. Disponível em:

$<$ http://gestaoesaude.unb.br/index.php/gestaoesaude/article/view/1225>. Acesso em: 30 jul. 2015.

JUNIOR, S. O. S.; FORTUNATO, M. M.; PESSOA, G. R.; PEREIRA, A. K. A. M.; NASCIMENTO, E. G. C.; ALCHIERE, J. C. Expressão da humanização no campo da atenção básica à saúde. Revista Rede de Cuidados em Saúde, Maringá, v. 9, n. 1, p. 1-13, jan. 2015.

JUNQUEIRA, R. M. P.; DUARTE, E. C. Internações hospitalares por causas sensíveis à atenção primária no Distrito Federal, 2008. Revista Saúde Pública, São Paulo, v. 46, n. 5, p. 761-768, out. 2012.

https://doi.org/10.1590/S0034-89102012000500001

LUDWIG, M. L. M.; BONILHA, A. L. L. O contexto de um serviço de emergência: com a palavra o usuário. Revista Brasileira de Enfermagem, Brasília, v. 56, n. 1, p. 12-17, fev. 2003.

MACHADO, L. M.; COLOMÉ, J. S.; BECK, C. L. C. Estratégia de Saúde da Família e o sistema de referência e de contrareferência: um desafio a ser enfrentado. Revista de Enfermagem da Universidade Federal de Santa Maria, Santa Maria, v. 1, n. 1, p. 31-40, abr. 2011.

MAIA, D. B.; SOUZA, E. T. G.; GAMA, R. M.; LIMA, J. C.; ROCHA, P. C. F.; SAAKI, Y. Atuação interdisciplinar na Atenção Básica de Saúde: a inserção da Residência Multiprofissional. Saúde \& Transformação Social, Florianópolis, v. 4, n. 1, p. 103-110, nov. 2013.

MARIN, M. J. S.; OLIVEIRA, M. A. C.; OTANI, M. A. P.; CARDOSO, C. P.; MORAVCIK, M. Y. A. D.; CONTERNO, L. O.; JUNIOR, A. C. S.; BRACCIALLI, L. A. D.; NUNES, C. R. R. A integração ensinoserviço na formação de enfermeiros e médicos: a experiência da FAMEMA. Ciência \& Saúde Coletiva, Rio de Janeiro, v. 19, n. 3, p. 967-974, mar. 2014.

MARQUES, A. S.; FREITAS, D. A.; LEÃO, C. D. A.; OLIVEIRA, S. K. M.; PEREIRA, M. M.; CALDEIRA, A. P. Atenção Primária e saúde materno-infantil: a percepção de cuidadores em uma comunidade rural quilombola. Ciência \& Saúde Coletiva, Rio de Janeiro, v. 19, n. 2, p. 365-371, fev. 2014.

MARQUES, G. Q.; LIMA M. A. D. S. Demandas de usuários a um serviço de pronto atendimento e seu acolhimento ao sistema de saúde. Revista Latinoamericana de Enfermagem, São Paulo, v. 15, n. 1, p. 13-19, jan/fev. 2007 https://doi.org/10.1590/S0104-11692007000100003

MATOS, F. V.; CERQUEIRA, M. B. R.; SILVA, A. W. M.; VELOSO, J. C. V.; MORAIS, K. V. A.; CALDEIRA, A. P. Egressos da Residência de Medicina de Família e Comunidade em Minas Gerais. Revista Brasileira de Educação Médica, Manguinhos, v. 38, n. 2, p. 198-204, jan. 2014.

MATUMOTO, S.; FORTUNA, C. M.; KAWATA, L. S.; MISHIMA, S. M.; PEREIRA, M. J. B. A prática clínica do enfermeiro na atenção básica: um processo em construção. Revista Latino-Americana de Enfermagem, Ribeirão Preto, v. 19, n. 1, p. 1-8, fev. 2011. 
MAZZUCHELLO, F. R.; CERETTA, L. B.; SCHWALM, M. T.; DAGOSTIM, V. S.; SORATTO, M. T. A atuação dos enfermeiros nos Grupos Operativos Terapêuticos na Estratégia Saúde da Família. O mundo da Saúde, São Paulo, v. 38, n. 4, p. 467-472, nov. 2014.

MEDEIROS, C. R. G.; JUNQUEIRA, A. G. W.; SCHWINGEL, G.; CARRENO, I.; JUNGLES, L. A. P.; SALDANHA, O. M. F. L. A rotatividade de enfermeiros e médicos: um impasse na implementação da Estratégia de Saúde da Família. Ciência \& Saúde Coletiva, Ribeirão Preto, v. 15, p. 1521-1531, set. 2010. https://doi.org/10.1590/S1413-81232010000700064

MELO, M. C.; QUELUCI, G. C.; GOUVÊA, M. V. Problematizando a residência multiprofissional em oncologia: protocolo de ensino prático na perspectiva de residentes de enfermagem. Revista Escola de Enfermagem da Universidade de São Paulo, São Paulo, v. 48, n. 4, p. 706-714, maio. 2014.

MORETTI-PIRES, R. O.; BUENO, S. M. V. Freire e formação para o Sistema Único de Saúde: o enfermeiro, o médico e o odontólogo. Acta Paulista de Enfermagem, São Paulo, v. 22, n. 4, p. 439-444, jul. 2009.

https://doi.org/10.1590/S0103-21002009000400015

MOURA, L. K. M.; LIMA, C. H. R.; SOUSA, F. D. L.; HONORATO, D. Z. S.; NETA, A. S. R.; COSTA, K. R. F. O profissional enfermeiro como educador: um olhar para atenção primária à saúde e o NASF. Revista Interdisciplinar, Teresina, v. 8, n. 1, p. 211-219, mar. 2015.

NASCIMENTO, D. D. G.; OLIVEIRA, M. A. C. A política de formação de profissionais da saúde para o SUS: considerações sobre a residência multiprofissional em saúde da família. Revista Mineira de Enfermagem, Belo Horizonte, v. 10, n. 4, p. 435-439, dez. 2006.

NÓBREGA, I. R. A. P.; ARRUDA, F. G. Residência Multiprofissional em Saúde do Idoso: relatando experiências à luz da Política Nacional de Humanização. Revista Portal de Divulgação, São Paulo, v. 27, n. 3 , p. 33-42, out. 2012. Disponível em: <http://portaldoenvelhecimento.org.br/revistanova/index.php/revistaportal/article/viewFile/304/304>. Acesso em: 01 jul. 2015.

OLIVEIRA, B. L. C. A.; SILVA, A. M.; CUNHA, C. L. F.; THOMAZ, E. B. A. F. Desigualdades socioeconômicas, demográficas e em saúde no nordeste brasileiro. Revista Pesquisa Saúde, São Luiz, v. 14, n. 3, p. 150-155, dez. 2013.

OLIVEIRA, K. K. D.; AMORIM. K. K. P. S.; FERNANDES, A. P. N. L.; MONTEIRO, A. I. Impacto da implementação do acolhimento com classificação de risco para o trabalho dos profissionais de uma Unidade de Pronto Atendimento. Revista Mineira de Enfermagem, Belo Horizonte, v. 17, n. 1, p. 148-156, set. 2013.

OLIVEIRA, S. N.; RAMOS, B. J.; PIAZZA, M.; PRADO, M. L.; REIBNITZ, S. K.; SOUZA, A. C. Unidade de Pronto Atendimento - UPA 24h: percepção da enfermagem. Texto Contexto Enfermagem, Florianópolis, v. 24, n. 1, p. 238-244, mar. 2015. https://doi.org/10.1590/0104-07072015003390011

PAIM, J.; TRAVASSO, C.; ALMEIDA, C.; BAHIA, L.; MACINKO, J. The Brazilian health system: history, advances, and challenges. The Lancet, London, v. 377, n. 9779, p. 1778-1797, may 2011.

https://doi.org/10.1016/S0140-6736(11)60054-8

PALMAS. Secretaria Municipal de Assuntos Jurídicos. Decreto n. ${ }^{\circ} 756$, de 15 de abril de 2014. Regulamenta o Programa Municipal de Bolsas de Estudo e Pesquisa para a Educação pelo Trabalho, e adota outras providências. Diário Oficial do município de Palmas, Palmas, TO, 16 abr. 2014. Disponível em: <http://legislativo.palmas.to.gov.br/media/leis/DECRETO\%20N\%C2\%BA\%20756-2014\%20de\%2015-042014\%2016-0-20.pdf>. Acesso em: 01 jun. 2015.

PEDROSA, I. C. F.; CORRÊA, A. C. P.; MANDÚ, E. N. T. Influências da infraestrutura de centros de saúde nas práticas profissionais: percepções de enfermeiros. Revista Ciência Cuidado e Saúde, Maringá, v. 10, n. 1, p. 058-065, mar. 2011. 
PUCCINI, P. T.; CORNETTA, V. K. Ocorrências em pronto-socorro: eventos sentinela para o monitoramento da atenção básica de saúde. Cadernos de Saúde Pública, Rio de Janeiro, v. 24, n. 9, p. 2032-2042, set. 2008. RABETTI, A. C.; FREITAS, S. F. T. Avaliação das ações em hipertensão arterial sistêmica na atenção básica. Revista Saúde Pública, São Paulo, v. 45, n. 2, p. 258-268, ago. 2011.

RAMALHO, B. L.; MADEIRA, V. P. C. A pós-graduação em educação no Norte e Nordeste: desafios, avanços e perspectivas. Revista Brasileira de Educação, Rio de Janeiro, v. 30, p. 70-81, dez. 2005.

RAMOS, M. J. M.; BEZERRA, M. I. C.; PAIVA, G. M. Saúde, ambiente e qualidade de vida: refexões da experiência da Residência Multiprofissional em Saúde da Família e Comunidade de Fortaleza-CE. Cadernos Escola de Saúde Pública, Ceará, v. 7, n. 2, p. 53-65, dez. 2013.

RANDOW, R. M. V.; BRITO, M. J. M.; SILVA, K. L.; ANDRADE, A. M.; CAÇADOR, B. S.; SIMAN, A. G. Articulação com atenção primária à saúde na perspectiva de gerentes de Unidade de Pronto Atendimento.

Revista Rede de Enfermagem do Nordeste, Fortaleza, v. 12, n. esp., p. 904-912, set. 2011.

SÁ, A. M. S.; MARTINS-SILVA, P. O.; FUNCHAL, B. Burnout: o impacto da satisfação no trabalho em profissionais de enfermagem. Pisicologia \& Sociedade, Florianópolis, v. 26, n. 3, p. 667-674, jun. 2014. https://doi.org/10.1590/S0102-71822014000300015

SCHWARTZ, T. D.; FERREIRA, J. T. B.; MACIEL, E. L. N.; LIMA, R. C. D. Estratégia Saúde da Família: avaliando o acesso ao SUS a partir da percepção dos usuários da Unidade de Saúde de Resistência, na região de São Pedro, no município de Vitória (ES). Ciência \& Saúde Coletiva, Ribeirão Preto, v. 15, n. 4, p. 2145-2154, nov. 2010. https://doi.org/10.1590/S1413-81232010000400028

SILVA, J. C.; CONTIM, D.; OHL, R. I. B.; CHAVAGLIA, S. R. R.; AMARAL, E. M. S. Percepção dos residentes sobre sua atuação no programa de residência multiprofissional. Acta Paulista de Enfermagem, São Paulo, v. 28, n. 2, p. 132-138, nov. 2015. https://doi.org/10.1590/1982-0194201500023

SILVA, T. A. M.; FRACOLLI, L. A.; CHIESA, A. M. Trajetória profissional na Estratégia Saúde da Família: em foco a contribuição dos cursos de especialização. Revista Latino-Americana de enfermagem, São Paulo, v. 19, n. 1, p. 1-8, fev. 2011.

SILVEIRA, R. P.; PINHEIRO, R. Entendendo a necessidade de médicos no interior da Amazônia - Brasil. Revista Brasileira de educação Médica, Manguinhos, v. 38, n. 4, p. 451-459, dez. 2014.

TADDEO, P. S.; GOMES, K. W. L.; CAPRARA, A.; GOMES, A. M. A.; OLIVEIRA, G. C.; MOREIRA, T. M. M. Acesso, prática educativa e empoderamento de pacientes com doenças crônicas. Ciência \& Saúde Coletiva, Ribeirão Preto, v. 17, n. 11, p. 2923-2930, nov. 2012. https://doi.org/10.1590/S141381232012001100009

TAKEMOTO, M. L. S.; SILVA, E. M. Acolhimento e transformações no processo de trabalho de enfermagem em unidades básicas de saúde de Campinas, São Paulo, Brasil. Caderno Saúde Pública, Rio de Janeiro, v. 23, n. 2, p. 331-340, fev. 2007.

VALERETTO, F. A.; SOUZA, M. C.; VORPAGEL, M. G. B. O Papel do Enfermeiro Integrante da Equipe da Estratégia de Saúde da Família em um município do interior paulista. Brazilian Journal of Health, São Paulo, v. 2, n. 3, p. 97-103, dez. 2011.

VITORIA, A. M.; HARZHEIM, E.; TAKEDA, S. P.; HAUSER, L. Avaliação dos atributos da atenção primária à saúde em Chapecó, Brasil. Revista Brasileira de Medicina da Família e Comunidade, Rio de Janeiro, v. 8, n. 29, p. 285-293, dez. 2013. Disponível em: <http://www.rbmfc.org.br/rbmfc/article/view/832>. Acesso em:01 jul. 2015. 